\title{
PENGARUH MODEL PEMBELAJARAN BERBASIS MASALAH TERHADAP KEMAMPUAN BERPIKIR KRITIS MATEMATIS SISWA KELAS VIII SMP
}

\author{
Dina Meilinda Br. Sirait \\ Universitas Katolik Santo Thomas, Medan; \\ dina.sirait85@gmail.com
}

\begin{abstract}
Abstrak. Penelitian ini bertujuan untuk: (1) Untuk mengetahui pengaruh model pembelajaran berbasis masalah terhadap kemampuan berpikir kritis matematika siswa SMP; (2) Untuk mengetahui sikap siswa terhadap model pembelajaran berbasis masalah. Populasi dalam penelitian ini adalah siswa kelas VIII SMP Negeri 28 Medan. Secara random sampling terpilih kelas VIII-F sebagai kelas eksperimen sebanyak 40 siswa dan kelas VIII-E sebagai kelas kontrol sebanyak 40 siswa. Data yang digunakan dalam penelitian ini merupakan data kuantitatif dan data kualitatif. Data kuantitatif yaitu data yang diperoleh dari tes kemampuan berpikir kritis siswa dan data kualitatif yaitu data yang diperoleh dari angket sikap siswa. Berdasarkan analisis data penelitian, diperoleh hasil sebagai berikut: (1) hasil analisis regresi diperoleh persamaan $\bar{Y}=51,89+23,57 \mathrm{X}$ memiliki arti bahwa model pembelajaran berbasis masalah berpengaruh positif dengan nilai ratarata sebesar 75,46 terhadap kemampuan berpikir kritis matematis siswa. Dari hasil korelasi diperoleh bahwa pengaruh model pembelajaran berbasis masalah cukup kuat dengan hasil koefisien korelasi sebesar 0,568 dan koefisien determinasi sebesar 32,3\% sehingga dapat disimpulkan bahwa model pembelajaran berbasis masalah berpengaruh terhadap kemampuan berpikir kritis matematis siswa. (2) Berdasarkan hasil respon sikap siswa disimpulkan bahwa respon siswa sangat positif terhadap model pembelajaran berbasis masalah dengan rata-rata sebesar $\geq 86.03$.
\end{abstract}

Kata Kunci. Pembelajaran berbasis masalah, berpikir kritis

\begin{abstract}
This study aims to: (1) To determine the effect of problem-based learning models on mathematics critical thinking skills of junior high school students; (2) To find out the attitudes of students towards the problem-based learning model. The population in this study were eighth grade students of Junior High School of 28 Medan. By random sampling selected class VIII-F as an experimental class as many as 40 students and class VIII-E as a control class as many as 40 students. The data used in this study are quantitative data and
\end{abstract}

Cartesius: Jurnal Pendidikan Matematika Vol. 2 No. 1

(P) Prodi Pendidikan Matematika Universitas Katolik Santo Thomas 
qualitative data. Quantitative data are data obtained from tests of students' critical thinking skills and qualitative data, namely data obtained from student attitude questionnaires. Based on the analysis of research data, obtained the following results: (1) the results of regression analysis obtained the equation = $51.89+23.57 X$ means that the problem-based learning model has a positive effect with an average value of 75.46 mathematical thinking skills of students . From the results of the correlation it was found that the influence of the problem-based learning model was strong enough with the results of the correlation coefficient of 0.568 and the coefficient of determination of $32.3 \%$ so it can be concluded that the problem-based learning model influences students' critical thinking skills. (2) Based on student attitudinal response results it can be concluded that the student response is very positive towards the problembased learning model with an average of $\geq 86.03$.

Keywords. Problem based learning, critical thinking

\section{PENDAHULUAN}

Matematika merupakan salah satu mata pelajaran yang mempunyai peranan penting dalam mempelajari ilmu pengetahuan lainnya. Kegiatan pembelajaran matematika di sekolah akan berlangsung dengan baik apabila siswa memiliki pemahaman konsep dan kemampuan berpikir kritis matematis.

Pembelajaran matematika di sekolah tidak hanya menekankan siswa menguasai materi matematika, melainkan juga dalam mencapai tujuantujuan dalam membangun kemampuan berpikir [1]. Secara umum, kemampuan matematika siswa Indonesia masih belum seperti yang diharapkan. Hal ini ditunjukkan oleh hasil The Trends International Mathematics and Science Study (TIMSS) tahun 2011. Hasil kajiannya adalah pada bidang studi matematika Indonesia menempati urutan ke-38 dengan skor 386 dari 42 negara yang diteliti dengan standar rata-rata pencapaian prestasi yaitu 500 .

Guru adalah salah satu tenaga kependidikan yang bertanggung jawab dalam berhasil atau tidaknya pelaksanaan proses pembelajaran [2]. Berhasil tidaknya seorang guru sangat tergantung pada fasilitas dan kualitas guru. Namun saat ini proses belajar-mengajar yang dilakukan oleh guru 
mengalami berbagai macam kendala. Masalah tersebut bukan hanya dapat melanda guru tetapi juga siswa yang pada akhirnya menyebabkan proses belajar mengajar tidak kondusif. Ketidakkondusifan suasana saat proses pembelajaran dapat berakibat pada kesulitan para peserta didik menangkap atau menerima materi yang diberikan oleh guru. Ketika siswa tidak mampu menerima materi yang disampaikan oleh guru, maka pada saat dilaksanakan ujian siswa akan merasa kesulitan mengerjakan soal. Oleh karena itu, untuk dapat membantu siswa, guru perlu mengetahui status perkembangan dan jenis kesulitan yang dihadapi siswa selama mengikuti proses pembelajaran di kelas [3]. Pada dasarnya guru biasanya memiliki makna sebagai seseorang yang ditiru atau diteladani, pembangun dan pemberi dorongan motivasi kepada siswanya. Sehingga apapun yang disampaikan dan dilakukan oleh guru akan menjadi dasar dan tiruan oleh siswa bahkan tersimpan dalam memori untuk jangka waktu yang lama. Jika seorang guru memiliki kemampuan berpikir kritis dalam mengajar, maka secara otomatis siswa akan memiliki kemampuan berpikir kritis. Oleh karena itu, seharusnya guru memberikan kesempatan kepada peserta didik untuk bisa mengembangkan kemampuan berpikir kritis dalam memahami pelajaran.

Berpikir kritis adalah sebuah kecakapan kognitif yang memungkinkan seseorang menginvestigasi sebuah situasi, masalah, pertanyaan, atau fenomena agar dapat membuat sebuah penilaian atau keputusan. Definisi yang lain bisa diartikan berpikir kritis adalah kemampuan berpikir dengan memberi alasan yang terorganisir dan mengevaluasi kualitas dari alasan tersebut secara sistematis serta memutuskan keyakinan [4].

Berpikir kritis mengandung aktivitas mental dalam hal memecahkan masalah, menganalisis asumsi, memberi rasional, mengevaluasi, melakukan penyelidikan, dan mengambil keputusan. Dalam proses pengambilan keputusan, kemampuan mencari, menganalisis dan mengevaluasi informasi sangatlah penting. Orang yang berpikir kritis akan mencari, menganalisis dan mengevaluasi informasi, membuat kesimpulan berdasarkan fakta kemudian melakukan pengambilan keputusan. Berpikir kritis merupakan proses terorganisasi dalam memecahkan masalah yang melibatkan aktivitas mental yang mencakup berbagai kemampuan. 
Kemampuan tersebut adalah merumuskan masalah, memberikan argumen, melakukan deduksi dan induksi, melakukan evaluasi, dan mengambil keputusan.

Pembelajaran matematika yang dilaksanakan di sekolah belum sepenuhnya mampu melatih kemampuan berpikir kritis siswa [5]. Oleh karena itu sampai saat ini perhatian atas pengembangan kemampuan berpikir kritis masih relatif rendah. Namun masih terbuka peluang untuk mengesplorasi kemampuan berpikir kritis serta pengembangannya. Untuk dapat mengembangkan kemampuan berpikir kritis matematis dalam pembelajaran guru perlu mendorong siswa untuk terlibat aktif dalam diskusi, bertanya serta menjawab pertanyaan, berpikir secara kritis, menjelaskan setiap jawaban yang diberikan, serta mengajukan alasan untuk setiap jawaban yang diajukan.

Dengan berpikir kritis peserta didik akan memiliki kebiasaan untuk berpikir mendalam dan menjalani hidup dengan pendekatan yang cerdas, seimbang dan dapat di pertanggungjawabkan. Sehingga dalam pemecahan masalah matematika peserta didik tidak hanya langsung asal menjawab saja melainkan menjawab dengan kesungguhan sesuai dengan pemahaman yang dimiliki dan penuh dengan pertimbangan sesuai dengan tahapan berpikir kritis hingga bisa mencapai tahapan terakhir.

Faktor lain penyebab rendahnya kemampuan berpikir kritis siswa terhadap matematika adalah metode pembelajaran yang digunakan guru. Misalnya dalam pembelajaran yang berorientasi pada pendekatan tradisional yang menempatkan siswa dalam proses belajar mengajar hanya sebagai pendengar. Kemampuan berpikir kritis siswa dapat dilatih dan ditingkatkan. Untuk dapat melatih dan meningkatkan kemampuan berpikir kritis siswa dapat dengan menerapkan model pembelajaran yang sesuai. Salah satu model pembelajaran yang diharapkan dapat membantu meningkatkan kemampuan berpikir kritis adalah model pembelajaran berbasis masalah atau problem based learning (PBL).

Cartesius: Jurnal Pendidikan Matematika Vol. 2 No. 1

CProdi Pendidikan Matematika Universitas Katolik Santo Thomas 
Pembelajaran berbasis masalah merupakan suatu pembelajaran yang berorientasi pada masalah kehidupan nyata sebagai upaya untuk meningkatkan kemampuan berpikir siswa dengan mengkontruksi pengetahuannya sendiri [6]. Dengan berusaha untuk mencari pemecahan masalah akan memberikan pengalaman nyata yang dengan pengalaman nyata tersebut para peserta didik belajar untuk berpikir kritis dalam aspek memberikan alasan. Berdasarkan teori yang dikembangkan Barrow, Min Liu menjelaskan karakteristik dari pembelajaran berbasis masalah, yaitu: proses pembelajaran dalam pembelajaran berbasis masalah menitikberatkan kepada siswa sebagai orang belajar dan masalah yang disajikan kepada siswa adalah masalah yang nyata dalam kehidupan sehari-hari sehingga siswa mampu dengan mudah memahami masalah serta dapat menerapkannya dalam kehidupan sehari-hari [7].

Selain pembelajaran yang masih tradisional, penyebab lain adalah adalah sikap siswa. Dalam proses pembelajaran terdapat dua sikap siswa yaitu sikap yang positif dimana siswa memperhatikan dan tenang dalam pembelajaran dan sikap negatif dimana siswa cenderung mengobrol sendiri dan tidak memperhatikan apa yang disampaikan oleh guru. Ketika diberi tugas atau soal untuk mengerjakan di depan kelas, siswa cenderung diam dan tidak ada yang dengan senang hati untuk mengerjakannya. Pada dasarnya dalam pembelajaran matematika siswa cenderung merespon dengan sikap negatif di mana siswa jarang menyelesaikan tugas matematika dan cemas dalam mengikuti pelajaran matematika.

Berdasarkan uraian di atas, maka perlu diperhatikan bahwa dalam pembelajaran matematika penggunaan model pembelajaran yang tepat sangat penting untuk mendukung kemampuan berpikir kritis siswa dalam proses pembelajaran. Oleh karena itu dilakukan penelitian untuk mengetahui Pengaruh Pembelajaran Berbasis Masalah Terhadap Kemampuan Berpikir Kritis Matematika Siswa kelas VIII SMP.

\section{METODE}

Penelitian ini merupakan penelitian yang menggunakan pendekatan kuantitatif dengan metode quasi eksperimen dengan Pretest-Posttest Control

Cartesius: Jurnal Pendidikan Matematika Vol. 2 No. 1

(CProdi Pendidikan Matematika Universitas Katolik Santo Thomas 
Group Design. Sehubungan dengan hal tersebut adapun yang menjadi variabel dalam penelitian ini ialah model pembelajaran berbasis masalah sebagai variabel bebas $(X)$ dan kemampuan berpikir kritis matematis sebagai variabel terikat $(\mathrm{Y})$.

Penelitian ini dilaksanakan di SMPN 28 Medan. Penelitian ini dilaksanakan pada tahun ajaran 2017/2018 semester ganjil. Populasi dalam penelitian ini adalah seluruh kelas VIII SMPN 28 Medan yang terbagi dalam 8 kelas yaitu kelas VIII-A, VIII-B, VIII-C, VIII-D, VIII-E, VIII-F, VIII-G, VIII-H. Dalam penelitian ini, sampel yang diteliti yaitu sampel yang bersifat homogen atau sampel yang sama. Maka peneliti menggunakan Simple Random Sampling. Dan yang terpilih adalah siswa kelas VIII-E dan siswa kelas VIII-F SMPN 28 Medan dengan jumlah siswa sebanyak 80 siswa.

Instrumen pengumpulan data yang digunakan adalah tes dan non tes. Tes yang dimaksud adalah tes kemampuan berpikir kritis, sedangkan non tes berupa angket sikap siswa terhadap model pembelajaran yang diterapkan. Soal tes untuk mengukur kemampuan berpikir kritis siswa yang terdiri dari masing-masing 5 soal uraian yang diberikan dalam bentuk pretes dan posttest pada pokok bahasan Sistem Persamaan Linier Dua Variabel (SPLDV).

Instrumen pengumpulan data dengan non tes yaitu berupa kuisioner (angket) dimana gunanya untuk mengetahui sikap belajar siswa, sehingga dapat dikelompokkan atas sikap positif dan sikap negatif. Instrumen untuk sikap disusun dengan terlebih dahulu membuat kisi-kisi yang diturunkan dan diterapkan berdasarkan indikator. Sikap belajar siswa terhadap matematika dapat diukur berdasarkan indikator-indikator berikut: (1) sikap terhadap pelajaran matematika, (2) sikap terhadap model pembelajaran, (3) sikap terhadap soal-soal yang diberikan. Berdasarkan indikator tersebut dikembangkan kuisioner sebanyak 25 butir pertanyaan yang disusun berdasarkan skala Likert dengan 4 (Empat) pilihan jawaban, yaitu SS (sangat setuju), S (setuju), TS (tidak setuju), dan STS (sangat tidak setuju). Selanjutnya hasil angket respon siswa dianaliss dengan persentase dari setiap jawaban siswa, dengan menggunakan rumus sebagai berikut:

Cartesius: Jurnal Pendidikan Matematika Vol. 2 No. 1

(CProdi Pendidikan Matematika Universitas Katolik Santo Thomas 


$$
\mathrm{P}=\frac{\sum K}{\sum N} \times 100 \%
$$

Keterangan:

$$
\begin{aligned}
& \mathrm{P}=\text { persentase respon siswa } \\
& \mathrm{K}=\text { siswa yang memilih option } \\
& \mathrm{N}=\text { jumlah siswa (responden) }
\end{aligned}
$$

Perangkat pembelajaran dan instrumen sebelum digunakan untuk penelitian terlebih dahulu divalidasi oleh ahli. Setelah itu diujicobakan. Lalu dilakukan uji validitas, uji reliabilitas, daya pembeda, dan uji tingkat kesukaran. Uji coba dilaksanakan di SMP RK Xaverius Namorambe pada siswa kelas IX

\begin{tabular}{|c|c|c|c|c|c|c|c|c|c|}
\hline \multirow[b]{2}{*}{$\begin{array}{c}\text { Jenis } \\
\text { data }\end{array}$} & \multirow[b]{2}{*}{$\begin{array}{l}\text { No. } \\
\text { Soal }\end{array}$} & \multicolumn{2}{|c|}{ Validitas } & \multicolumn{2}{|c|}{ Reliabilitas } & \multicolumn{2}{|c|}{$\begin{array}{c}\text { Daya } \\
\text { pembeda }\end{array}$} & \multicolumn{2}{|c|}{$\begin{array}{c}\text { Tingkat } \\
\text { Kesukaran }\end{array}$} \\
\hline & & $\begin{array}{c}\text { Koef. } \\
\text { Kor }\end{array}$ & $\begin{array}{c}\text { Inter } \\
\text { pretasi }\end{array}$ & $\begin{array}{l}\text { Koef } \\
\text { kord }\end{array}$ & $\begin{array}{c}\text { Inter } \\
\text { pret } \\
\text { asi }\end{array}$ & $\begin{array}{c}\text { koe } \\
\text { f.k } \\
\text { or } \\
\end{array}$ & $\begin{array}{l}\text { interp } \\
\text { retasi }\end{array}$ & $\begin{array}{c}\text { koef } \\
\text { Kor }\end{array}$ & $\begin{array}{c}\text { Inter } \\
\text { preta } \\
\text { si }\end{array}$ \\
\hline \multirow{10}{*}{ 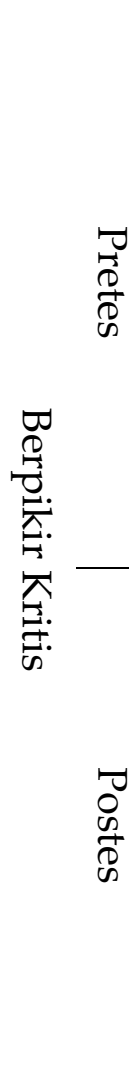 } & 1 & 0,786 & Valid & \multirow{5}{*}{0,84} & \multirow{5}{*}{ Baik } & 0,44 & Baik & 0,50 & $\begin{array}{c}\text { Seda } \\
\text { ng }\end{array}$ \\
\hline & 2 & 0,844 & Valid & & & 0,47 & Baik & 0,41 & $\begin{array}{c}\text { Seda } \\
\text { ng }\end{array}$ \\
\hline & 3 & 0,718 & Valid & & & 0,45 & Baik & 0,40 & $\begin{array}{c}\text { Seda } \\
\text { ng }\end{array}$ \\
\hline & 4 & 0,726 & Valid & & & 0,47 & Baik & 0,39 & $\begin{array}{c}\text { Seda } \\
\text { ng }\end{array}$ \\
\hline & 5 & 0,852 & Valid & & & 0,44 & Baik & 0,44 & $\begin{array}{c}\text { Seda } \\
\text { ng }\end{array}$ \\
\hline & 1 & 0,470 & Valid & \multirow{5}{*}{0,60} & \multirow{5}{*}{ Baik } & 0,24 & Cukup & 0,42 & $\begin{array}{c}\text { Seda } \\
\text { ng }\end{array}$ \\
\hline & 2 & 0,741 & Valid & & & 0,33 & Baik & 0,47 & $\begin{array}{c}\text { Seda } \\
\text { ng }\end{array}$ \\
\hline & 3 & 0,560 & Valid & & & 0,31 & Cukup & 0,42 & $\begin{array}{c}\text { Seda } \\
\text { ng }\end{array}$ \\
\hline & 4 & 0,641 & Valid & & & 0,31 & Cukup & 0,41 & $\begin{array}{c}\text { Seda } \\
\text { ng }\end{array}$ \\
\hline & 5 & 0,673 & Valid & & & 0,42 & Baik & 0,43 & Seda \\
\hline
\end{tabular}
SMP dengan jumlah siswa 23 orang. Hasil analisis data uji coba disajikan pada tabel berikut:

Tabel 1. Rekapitulasi Analisis Uji Coba Tes Kemampuan Berpikir Kritis

Cartesius: Jurnal Pendidikan Matematika Vol. 2 No. 1

CProdi Pendidikan Matematika Universitas Katolik Santo Thomas 
Pengolahan data kuantitatif dilakukan melalui uji prasyarat statistik yang diperlukan sebagai dasar dalam pengujian hipotesis yaitu uji normalitas sebaran data subyek sampel dan uji homogenitas varians. Untuk menguji normalitas data juga dapat menggunakan uji normalitas kolmogorov-Smirnov ${ }^{n}$ Test dengan SPSS 22 for mindows. Dimana data dikatakan berdistribusi normal apabila nilai probabilitas atau signitifikasi kolmogorov-Smirnov ${ }^{n}$ Test $>$ 0,5. Sedangkan untuk menguji homogenitas digunakan uji Lavene dengan menggunakan SPSS 22 for mindows. Dimana data yang diperoleh dikatakan homogen apabila nilai probabilitas atau signitifikasi Levene $>0,05$.

Uji hipotesis dilakukan untuk mengetahui apakah hipotesis yang diajukan dalam penelitian ini diterima atau ditolak. Pengujian hipotesis dilakukan dengan teknik uji statistik yang cocok dengan distribusi data yang diperoleh. Dalam pengujian hipotesis penelitian ini akan diuji dengan menggunakan analisis regresi linier sederhana dan korelasi.

\section{HASIL DAN PEMBAHASAN}

\section{HASIL}

Secara umum deskripsi kedua kelompok data kemampuan berpikir kritis matematis siswa disajikan pada tabel berikut ini:

Tabel 2. Deskripsi Pretes dan Postes Kemampuan Berpikir Kritis Matematis Siswa Kelas Eksperimen dan Kelas kontrol

\begin{tabular}{ccccc}
\hline \multirow{2}{*}{ Nilai } & \multicolumn{2}{c}{ Kelas Eksperimen } & \multicolumn{2}{c}{ Kelas Kontrol } \\
\cline { 2 - 5 } & Pretest & Postest & Pretest & Postest \\
\hline N & 37 & 37 & 37 & 37 \\
Terendah & 12 & 40 & 12 & 24 \\
Tertinggi & 92 & 100 & 84 & 92 \\
Rata-rata & 46,38 & 75,46 & 47,35 & 51,89 \\
St. Deviasi & 23,24 & 15,89 & 21,80 & 18,61 \\
Varians & 539,96 & 252,59 & 475,12 & 346,21 \\
\hline
\end{tabular}

Maka berdasarkan tabel di atas terlihat bahwa kemampuan berpikir kritis matematis siswa di kelas eksperimen (kelas yang mengikuti pembelajaran dengan model pembelajaran berbasis masalah) lebih tinggi dibandingkan 
dengan siswa dikelas kontrol (kelas yang mengikuti pembelajaran konvensional).

Sebelum dilakukan pengujian hipotesis perlu dilakukan pengujian prasyarat analisis terlebih dahulu terhadap data hasil penelitian. Berikut merupakan hasil perhitungan uji normalitas kemampuan awal (pretest) berpikir kritis siswa di kelas eksperimen dan kelas kontrol disajikan pada tabel berikut:

Tabel 3. Hasil Uji Normalitas Pretes Kemampuan Berpikir Kritis Matematis Siswa Kelas Eksperimen dan Kelas Kontrol

\begin{tabular}{cccc}
\hline & \multicolumn{3}{c}{ Kolmogorov-Smirnov $^{\mathbf{a}}$} \\
\cline { 2 - 4 } & Statistic & df & Sig. \\
\hline pretest_eksperimen &, 122 & 37 &, 183 \\
pretest_kontrol &, 137 & 37 &, 077 \\
\hline
\end{tabular}

Berdasarkan hasil perhitungan pada tabel 3, nilai signifikan untuk kelas eksperimen sebesar 0,183 dan nilai signifikan untuk kelas kontrol sebesar 0,077. Kedua nilai signifikan tersebut lebih besar dari taraf signifikan 0,05, sehingga dapat disimpulkan kedua kelas tersebut berdistribusi normal $\left(\mathrm{H}_{a}\right.$ diterima).

Adapun hasil perhitungan uji normalitas kemampuan akhir (postest) berpikir kritis siswa di kelas eksperimen dan kelas kontrol disajikan pada tabel berikut:

Tabel 4. Hasil Uji Normalitas Postes Kemampuan Berpikir Kritis Matematis Siswa Kelas Eksperimen dan Kelas Kontrol

\begin{tabular}{lccrr}
\hline & \multicolumn{3}{c}{ Kolmogorov-Smirnov $^{\mathbf{a}}$} \\
\cline { 2 - 5 } & \multicolumn{2}{c}{ Statistic } & df & Sig. \\
\hline postes_eksperimen &, 117 & 37 &, $200^{*}$ \\
postes_kontrol &, 123 & 37 &, 168 \\
\hline
\end{tabular}

Berdasarkan hasil perhitungan pada tabel 4 nilai signifikan untuk kelas eksperimen sebesar 0,200 dan nilai signifikan untuk kelas kontrol sebesar 0,168. Kedua nilai signifikan tersebut lebih besar dari taraf signifikan 0,05, sehingga dapat disimpulkan kedua kelas tersebut berdistribusi normal $\left(\mathrm{H}_{a}\right.$ diterima). Selanjutnya akan dilakukan uji homogenitas apakah varians 
keseluruhan aspek kelompok model pembelajaran berbasis masalah dan model konvensional sama. Berikut hasil perhitungan uji homogenitas siswa:

Tabel 5. Test of Homogeneity of Variances

Tes Kemampuan Awal Kelas Eksperimen dan Kelas Kontrol

\begin{tabular}{cccc}
\hline Levene Statistic & df1 & df2 & Sig. \\
\hline, 005 & 1 & 72 &, 941 \\
\hline
\end{tabular}

Berdasarkan tabel 5, hasil uji homogenitas terlihat nilai signifikan statistik uji levene statistic sebesar 0.941. Nilai signifikan tersebut lebih besar dari taraf signifikan 0.05, maka Ho diterima yang berarti sampel berasal dari kelompok data yang homogen.

Analisis regresi linear sederhana adalah hubungan secara linear antara satu variabel independen $(\mathrm{X})$ dan variabel dependen $(\mathrm{Y})$. Berdasarkan hasil olah data maka diperoleh persamaan regresi sebagai berikut.

Tabel 6. Hasil Analisis Regresi

\begin{tabular}{cccccc}
\hline \multirow{2}{*}{ Model } & $\begin{array}{c}\text { Unstandardized } \\
\text { Coefficients }\end{array}$ & $\begin{array}{c}\text { Standardize } \\
\text { Coefficients }\end{array}$ & T & Sig. \\
\cline { 2 - 4 } & B & $\begin{array}{c}\text { Std. } \\
\text { Error }\end{array}$ & Beta & & \\
\hline \multirow{2}{*}{$\begin{array}{c}\text { (Constant) } \\
\text { pembelajaran_be } \\
\text { rbasis_masalah }\end{array}$} & 51,892 & 2,845 & & 18,242 &, 000 \\
\hline
\end{tabular}

Berdasarkan tabel 6 diperoleh nilai konstanta adalah 51.892 sedangkan nilai koefisien regresi sebesar 23.568. Persamaan yang diperoleh sebagai berikut:

$$
\hat{Y}=51.892+23.568 X
$$

Selanjutnya untuk menguji kelinieran dan keberartian (signifikansi) regresi, dapat dilihat pada tabel ANAVA berikut ini:

Tabel 7. Analisis Varians Untuk Uji Kelinieran dan Keberartian Regresi

\begin{tabular}{cccccc}
\hline Sumber variasi & Dk & JK & RJK & Fhitung & F $_{\text {tabel }}$ \\
\hline Total & 74 & 331872 & - & - & - \\
\hline
\end{tabular}

Cartesius: Jurnal Pendidikan Matematika Vol. 2 No. 1

CProdi Pendidikan Matematika Universitas Katolik Santo Thomas 


\begin{tabular}{lccllll}
\hline Regresi(a) & 1 & 300039.784 & 300039.784 & & \\
Regresi(b la) & 1 & 10275.648 & 10273.032 & 34.32 & 3.97 \\
Sisa & 72 & 21556.57 & 229.397 & & \\
Tuna cocok & 15 & -0.202 & -0.0135 & -0.000036 & 1.85 \\
Galat & 57 & 21566.77 & 378.19 & & \\
\hline
\end{tabular}

Berdasarkan tabel 7, untuk menguji hipotesis (i) kelinieran regresi diperoleh nilai $\mathrm{F}_{\text {tabel }}=1.85$ dan $\mathrm{F}_{\text {hitung }}=-0.000036$. Karena Fhitung $<\mathrm{F}_{\text {tabel }}$ maka $\mathrm{H}_{\mathrm{o}}$ ditolak dan $\mathrm{H}_{a}$ diterima yang berarti bahwa bentuk regresi linier. Untuk menguji hipotesis (ii) signifikansi regresi diperoleh nilai $\mathrm{F}_{\text {tabel }}=3.97$ dan $\mathrm{F}_{\text {hitung }}=34,32$. Karena Fhitung $>$ Ftabel maka Ho ditolak dan $\mathrm{H}_{a}$ diterima yang berarti koefisien arah regresi nyata sifatnya sehingga regresi yang diperoleh berarti (signifikan).

Karena bentuk hubungan antara peubah respon $Y$ (kemampuan berpikir kritis matematis) dan peubah prediktor $\mathrm{X}$ (model pembelajaran berbasis masalah) linier dan berarti (signifikan), maka selanjutnya mengetahui kekuatan hubungan model pembelajaran berbasis masalah terhadap kemampuan berpikir kritis matematis siswa.

Tabel 8. Correlations

\begin{tabular}{|c|c|c|c|}
\hline & & $\begin{array}{c}\text { kemampuan_ber } \\
\text { pikir_kritis }\end{array}$ & $\begin{array}{c}\text { pembelajaran_ber } \\
\text { basis_masalah }\end{array}$ \\
\hline \multirow{3}{*}{$\begin{array}{c}\text { kemampuan_berpi } \\
\text { kir_kritis }\end{array}$} & $\begin{array}{c}\text { Pearson } \\
\text { Correlation }\end{array}$ & 1 &, $568^{* *}$ \\
\hline & Sig. (2-tailed) & & ,000 \\
\hline & $\mathrm{N}$ & 74 & 74 \\
\hline \multirow{3}{*}{$\begin{array}{c}\text { pembelajaran_berb } \\
\text { asis_masalah }\end{array}$} & $\begin{array}{c}\text { Pearson } \\
\text { Correlation }\end{array}$ &, $568^{* *}$ & 1 \\
\hline & Sig. (2-tailed) & ,000 & \\
\hline & $\mathrm{N}$ & 74 & 74 \\
\hline
\end{tabular}

Dari hasil SPSS diperoleh koefisien korelasi $(\mathrm{r})=0.568$ dan koefisien determinasi $\left(\mathrm{r}^{2}\right)=32,3 \%$. Dengan demikian dapat disimpulkan bahwa model pembelajaran berbasis masalah mempunyai hubungan yang cukup kuat terhadap kemampuan berpikir kritis matematis siswa sebesar $(r)=0.568$ dan terdapat pengaruh model pembelajaran berbasis masalah terhadap 
kemampuan berpikir kritis matematis siswa pada materi sistem persamaan linier dua variabel sebesar $32.2 \%$.

Setelah koefisien korelasi dan koefisien determinasi diperoleh, maka selanjutnya dilakukan pengujian koefisien korelasi untuk mengetahui apakah korelasi yang telah diperoleh berarti atau tidak. Berdasarkan perhitungan uji keberartian korelasi, diperoleh tabel $=1.666$ dengan $\mathrm{dk}=\mathrm{n}-2=$ 72 dan tabel $=5,88$. Dengan demikian thitung $>t_{\text {tabel }}$ maka $\mathrm{H}_{\mathrm{o}}$ ditolak dan $\mathrm{H}_{\mathrm{a}}$ diterima yang artinya terdapat pengaruh yang berarti antara model pembelajaran berbasis masalah terhadap kemampuan berpikir kritis matematis siswa.

Tujuan yang ingin diperoleh dari penelitian ini adalah untuk mengetahui bagaimana respon sikap siswa. Hasil respon sikap siswa dapat dilihat pada tabel berikut:

Tabel 9. Hasil Persentase Respon Siswa Berdasarkan Sikap Siswa

\begin{tabular}{|c|c|c|c|c|c|}
\hline \multirow[b]{2}{*}{ Sikap } & \multirow[b]{2}{*}{ Indikator } & \multirow[b]{2}{*}{$\begin{array}{c}\text { No.Butir } \\
\text { Angket }\end{array}$} & \multirow[b]{2}{*}{ Jumlah } & \multicolumn{2}{|c|}{ Pesentase Respon } \\
\hline & & & & $\begin{array}{l}\text { Positif } \\
\text { (setuju) }\end{array}$ & $\begin{array}{c}\text { Negatif } \\
\text { (tidak } \\
\text { Setuju) }\end{array}$ \\
\hline \multirow{4}{*}{$\begin{array}{c}\text { Terhadap } \\
\text { Pelajaran } \\
\text { Matematika }\end{array}$} & $\begin{array}{l}\text { 1. Kesukaan siswa } \\
\text { terhadap } \\
\text { pelajaran } \\
\text { matematika. }\end{array}$ & $6,10,12$ & 3 & $73,87 \%$ & $26,13 \%$ \\
\hline & $\begin{array}{l}\text { 2. Sikap siswa } \\
\text { terhadap } \\
\text { pembelajaran } \\
\text { matematika. }\end{array}$ & $4,8,9$ & 3 & $89,18 \%$ & $10,82 \%$ \\
\hline & $\begin{array}{l}\text { 3. Peran guru } \\
\text { dalam } \\
\text { pembelajaran } \\
\text { matematika. }\end{array}$ & $5,14,14,16$ & 4 & $94,595 \%$ & $5,405 \%$ \\
\hline & $\begin{array}{l}\text { 4. Manfaat } \\
\text { matematika } \\
\text { dalam belajar } \\
\text { matematika } \\
\text { dalam } \\
\text { kehidupan } \\
\text { sehari-hari. }\end{array}$ & $2,3,13$ & 3 & $92,793 \%$ & $7,207 \%$ \\
\hline $\begin{array}{c}\text { Terhadap } \\
\text { Model } \\
\text { Pembelajaran }\end{array}$ & $\begin{array}{l}\text { 1. Kesukaan siswa } \\
\text { terhadap model } \\
\text { pembelajaran. }\end{array}$ & $1,7,11$ & 3 & $90,088 \%$ & $9,912 \%$ \\
\hline
\end{tabular}

Cartesius: Jurnal Pendidikan Matematika Vol. 2 No. 1

(CProdi Pendidikan Matematika Universitas Katolik Santo Thomas 


\begin{tabular}{|c|c|c|c|c|c|}
\hline & $\begin{array}{l}\text { 2. Manfaat } \\
\text { mengikuti } \\
\text { model } \\
\text { pembelajaran. }\end{array}$ & 19,21 & 2 & $75,676 \%$ & $24,324 \%$ \\
\hline \multirow{3}{*}{$\begin{array}{c}\text { Terhadap } \\
\text { Soal-soal yang } \\
\text { diberikan }\end{array}$} & $\begin{array}{l}\text { 1. Kesukaan siswa } \\
\text { terhadap soal- } \\
\text { soal yang } \\
\text { diberikan. }\end{array}$ & $\begin{array}{c}17,18,20 \\
25\end{array}$ & 4 & $92,568 \%$ & $7,432 \%$ \\
\hline & $\begin{array}{l}\text { 2. Manfaat soal- } \\
\text { soal yang } \\
\text { diberikan dalam } \\
\text { kehidupan. } \\
\text { sehari-hari. }\end{array}$ & $22,23,24$ & 3 & $91,892 \%$ & $8,108 \%$ \\
\hline & Jumlah & & 25 & & \\
\hline
\end{tabular}

Berdasarkan hasil analisis respon siswa di atas dapat disimpulkan bahwa siswa memiliki sikap positif terhadap (1) pelajaran matematika, (2) model pembelajaran berbasis masalah, dan (3) soal-soal yang diberikan. Disebabkan oleh hasil dari persentase respon sikap siswa yang menyatakan setuju lebih besar dari pada hasil persentase respon siswa yang menyatakan tidak setuju.

\section{PEMBAHASAN}

Dari hasil penelitian diperoleh nilai rata-rata kelas eksperimen yang menggunakan model pembelajaran berbasis maslah adalah sebesar 75.46 dan nilai rata-rata kelas kontrol yang menggunakan pembelajaran konvensional adalah sebesar 51.89 .

Hal tersebut juga didukung dengan hasil uji hipotesis yang menggunakan uji regresi linier sederhana dan korelasi. Berdasarkan hasil perhitungan koefisien korelasi dengan menggunakan rumus product moment diperoleh koefisien korelasi $(r)=0,568$ artinya model pembelajaran berbasis masalah mempunyai hubungan yang cukup kuat terhadap kemampuan berpikir kritis matematis siswa, dan terdapat pengaruh model pembelajaran berbasis masalah terhadap kemampuan berpikir kritis matematis siswa pada sebesar $32.2 \%$ selebihnya dipengaruhi oleh faktor lain yang tidak dianalisis dalam penelitian ini.

Hasil pengujian hipotesis diperoleh bahwa Ho ditolak dan Ha diterima, dengan demikian rata-rata kemampuan berpikir kritis matematis siswa yang mengikuti pembelajaran dengan model pembelajaran berbasis masalah lebih 
tinggi dibandingkan dengan siswa yang mengikuti pembelajaran konvensional. Hal ini dibuktikan dari hasil perhitungan secara statistik dimana thitung $>t_{\text {tabel }}=5,88>1,666$. Hasil penelitian ini menunjukkan bahwa model pembelajaran berbasis masalah berpengaruh terhadap kemampuan berpikir kritis matematis siswa.

Selain itu, untuk memperkuat hasil uji hipotesis dalam penelitian ini maka dilakukan analisis respon sikap siswa terhadap model pembelajaran berbasis masalah dengan menggunakan angket. Hasilnya disimpulkan bahwa respon siswa sangat positif terhadap model pembelajaran berbasis masalah karena persentase respon siswa yang menyatakan setujuan lebih besar dari pada persentase respon yang menyatakan ketidak setujuan.

\section{KESIMPULAN}

Berdasarkan hasil penelitian yang dilaksanakan mengenai model pembelajaran berbasis masalah terhadap kemampuan berpikir kritis matematis siswa di SMP Negeri 28 Medan diperoleh beberapa kesimpulan sebagai berikut:

1. Berdasarkan hasil analisis dan regresi diperoleh bahwa pengaruh model pembelajaran berbasis masalah terhadap kemampuan berpikir kritis siswa SMPN 28 Medan berpengaruh positif dengan koefisien korelasi 0,568 artinya model pembelajaran berbasis masalah mempunyai hubungan yang cukup kuat terhadap kemampuan berpikir kritis matematis siswa dan terdapat pengaruh model pembelajaran berbasis masalah terhadap kemampuan berpikir kritis matematis siswa sebesar $32.3 \%$ selebihnya dipengaruhi oleh faktor lain. Dari hasil uji hipotesis diperoleh nilai (thitung $>t_{\text {tabel }}=5,88>1,666$ ). Hal ini berarti bahwa $H_{a}$ diterima dan $\mathrm{H}_{0}$ ditolak hal ini menunjukkan bahwa model pembelajaran berbasis masalah berpengaruh terhadap kemampuan berpikir kritis matematis siswa.

2. Berdasarkan hasil analisis respon sikap siswa terhadap model pembelajaran berbasis masalah, respon sikap siswa sangat positif terhadap model pembelajaran berbasis masalah karena persentase respon siswa yang menyatakan rsetujuan lebih besar dari pada persentase respon yang menyatakan ketidaksetujuan. 


\section{UCAPAN TERIMAKASIH}

Terimakasih penulis sampaikan kepada program studi Pendidikan Matematika Universitas Katolik Santo Thomas dalam hal ini dosen pembimbing 1 yaitu Ibu Sinta Dameria Simanjuntak, S.Si., M.Pd dan dosen pembimbing 2 yaitu Bapak Arisan Candra Nainggolan, S.Pd., M.Pd. yang sudah membantu dalam penulisan skripsi dan artikel ini. Semoga hasil dari penelitian ini bermanfaat bagi perkembangan ilmu pengetahuan.

\section{DAFTAR PUSTAKA}

[1] F. Daniel, "Kemampuan Berpikir Kritis Siswa Pada Implementasi Project Based Learning (PJBL) Berpendekatan Saintifik," JPMI (Jurnal Pendidik. Mat. Indones., Vol. 1, No. 1, pp. 7-13, 2016.

[2] H. Hasan, "Kendala Yang Dihadapi Guru Dalam Proses Belajar Mengajar Matematika Di SD Negeri Gani Kabupaten Aceh Besar," Pendidik. Guru Sekol. Dasar J. PESONA DASAR Univ. Syiah Kuala, Vol. 1, No. 4, pp. 4051, 2015.

[3] I. Yasir, "Evaluasi Diagnostik Dan Remedial Oleh Guru," J. BAPPEDA, Vol. 2, No. 3, pp. 186-192, 2016.

[4] M. Ikhsan and S. Rizal, "Penerapan Model Pembelajaran Berbasis Masalah untuk Meningkatkan Kemampuan Berpikir Kritis dan Disposisi Matematis Siswa," J. Didakt. Mat., Vol. V1, No. 1, pp. 71-82, 2014.

[5] E. Sulistiani and Masrukan, "Pentingnya Berpikir Kritis dalam Pembelajaran Matematika untuk Menghadapi Tantangan MEA," Semin. Nas. Mat. X Univ. Negeri Semarang 2016, pp. 605-612, 2016.

[6] M. Sari, Lisna Siti Permana dan Rahadi, "Jurnal Pendidikan Matematika Volume 3, Nomor 2, Mei 2014," J. Pendidik. Mat., Vol. 3, No. 3, pp. 143150, 2014.

[7] Shoimin, A., "Model Pembelajaran Inovatif Dalam Kurikulum 2013, Yogyakarta: Ar-ruzz Media. 